\title{
Motivation in Personnel Management of a Trading Enterprise
}

Submitted 03/02/19, $1^{\text {st }}$ revision 07/03/19, $2^{\text {nd }}$ revision 15/4/19 accepted 18/06/19

\author{
I.N. Sycheva ${ }^{1}$, O.Yu. Voronkova ${ }^{2}$, I.V. Kovaleva ${ }^{3}$, \\ A. F. Kuzina ${ }^{4}$, S.A. Bannikov ${ }^{5}$, S.V. Titova ${ }^{6}$
}

\begin{abstract}
:
Purpose: Investigating the problems of personnel motivation efficiency as one of the most significant factors of the success of an enterprise at the present stage of development of the Russian economy, the authors consider expedient to consider the theory and practice of the personnel motivation system in a commercial enterprise.

Design: General scientific (analysis, synthesis, comparison), and special methods of research (economic and statistical, balance sheet, design-calculation and other), document analysis, questioning, and others were used during the study.

Findings: The authors revealed that the trading company should focus on the development of a system of motivation in two directions: the improvement of material motivation of staff and the improvement of non-material motivation of staff. Improving the proposed system of staff motivation will allow the company to create a favorable atmosphere in the team, increasing turnover.

Practical implications: The obtained results can be used by the head of the enterprise when developing plans to improve the management system and increase investment attractiveness.

Originality: This article analyzes the theoretical foundations of motivation in personnel management. Given the organizational and economic characteristics of the trading enterprise, identified the existing system of motivation in the enterprise.
\end{abstract}

Keywords: Motivation, practices, personnel management, organizational structure, system modernization.

JEL codes: $O 13, Q 24, Q 57$.

Paper type: Research article in Special Issue dedicated to Russian Economy.

Section 3: Management Systems.

${ }^{1}$ I.I. Polzunov Altai state technical university, Russian Federation, Barnaul, Russia. E-mail: madam.si4eva2010@yandex.ru

${ }^{2}$ Altai state University, Barnaul, Russia. E-mail: olka2004@yandex.ru

${ }^{3}$ Altai state agricultural University, Barnaul, Russia. E-mail:

irakovaleva20051@ rambler.ru

${ }^{4}$ Kuban State Agrarian University named after I.T. Trubilin, Krasnodar, Russia.

${ }^{5}$ Financial University under the Government of the Russian Federation, Moscow, Russia.

${ }^{6}$ Kazan Innovative University named after V.G. Timiryasov (IEML), Kazan, Russia. 


\section{Introduction}

At the present stage of economic development, it becomes evident that management systems cannot be successful without an effective motivation system. Personnel motivation is the primary means to ensure the use of resources, of the total enterprise personnel (Anurova, 2018). Creating a cohesive team of experienced professionals working for the common benefit and well-being is a continuous process in an enterprise (Rozanova, 2014). To ensure the effective use of personnel motivation, it is necessary to provide its interests, needs, nature, expectations, attitudes, aspirations, and orientations (Kaverin, 2014). The motivation system, if correctly applied and designed by the head of the company, is the primary personnel management tool. Assessment of the existing enterprise system helps to identify errors in the motivation system, its strengths, and weaknesses and reveals the existing problems and solutions to the head of the company. All this eventually leads to the effective functioning of an enterprise in the market (Korableva et al., 2018; Danko \& Golubev, 2014).

The purpose of this work is to improve the personnel motivation system in a commercial enterprise. The accomplishment of this purpose is guided by the following objectives:

1) to analyze the theoretical basis of motivation in personnel management;

2) to provide the organizational and economic characteristics of a trading enterprise, to identify the existing system of motivation;

3) to suggest practices for effective personnel motivation of a trading enterprise;

The object of this study is a trading enterprise. The subject of research is the system of motivation in personnel management.

\section{Literature Review}

In Russian economic literature, the motivation of personnel is understood as the employee's desire to meet his needs (to get certain benefits) through work (Solomatina et al., 2016). Depending on the purpose and characteristics of motivation at an enterprise, motivation can be ongoing and performance-based (reward or punishment) (Repin, 2016; Goloshchapova et al., 2018).

\section{Contextual theories of motivation:}

1) The classic motivational theory is Maslow's needs theory is described in the "Theory of Human Motivation" in 1943. Maslow divided the needs into 5 categories that can be arranged in the form of a hierarchical structure: physiological - the primary human needs (oxygen, water, food, comfort); security - for safety from danger, attack, threat; social - the need to feel like a member of a community, a group of people; esteem - the need for respect and recognition of personal qualities and achievements; self-actualization - the need to fulfill one's potential 
(Serbinskii \& Samygina, 2015). The highest-level needs do not motivate a person until his or her lower-level needs are met, at least partially.

2) The theory of motivation by Clayton Alderfer is a slightly revised hierarchy of Maslow's needs theory. He proposed to define three major groups of needs: a) the need for existence (Existence) - physiological needs; b) the need for communication (Relatedness) - involvement in society; c) the need for growth (Growth) - self-expression, self-realization, creativity. The difference between Alderfer's theory and Maslow's pyramid is that the movement along the levels of needs goes both ways. Maslow's model implies only one direction - from the bottom to the top (Domozhilkina \& Dzhabbarova, 2016; Kuznetsov and Suprun, 2017; Daryin et al., 2015; Lorincová et al., 2019).

3) The two-factor theory of motivation by Herzberg. He defined factors that have a motivating and demotivating effect on a person. He believed that an employee's satisfaction and dissatisfaction are due to various factors that Frederick divided into two broad categories: hygiene factors and motivating factors. Motivators that lead to job satisfaction are associated with job content and are caused by the inner needs of an individual in self-expression. Therefore, they are called "internal" motivation factors (Nikolaeva et al., 2017). Hygienic factors are associated with external conditions and deficiencies of work. According to Herzberg, the factors causing satisfaction and dissatisfaction with work are not opposites in the same dimension (Lyasko, 2015). In other words, hygienic factors can create a bad situation, but they cannot lead to great satisfaction; at best, they can create a neutral situation. Job satisfaction is caused only by motivational factors, the positive development of which can increase motivation and satisfaction from a neutral to a positive state (Blank, 2015).

4) The next contextual theory of motivation is David McClelland's needs theory, which focuses on three main driving motivators: a) the need for achievement; b) the need for power; c) the need for affiliation. McClelland's theory of acquired needs means the following: the need for affiliation encourages people to work in a team, strive for recognition; the need for power motivates them for growth, initiative, and leadership; the need for achievement motivates them to take responsibility in managing complex tasks, to address them successfully, and to achieve the objective of an organization (Dedyukina \& Ronova, 2015; Brager et $a l ., 2018$ ). Therefore, employees with a need for affiliation must be given a job with social dialogue opportunities. Personnel with the need for power should be given an opportunity to lead, to make decisions on their own. Workers with the need for achievement should be entrusted with interesting and difficult tasks (but those with which they can cope with), rewarding and noting their success (Minasyan, 2014).

Procedural theories of motivation:

1) The X-Y theory by D. McGregor. 
The manager can directly or indirectly regulate the behavior of employees at the workplace through tasks, organizational resources, organizational environment, ongoing control, task fulfillment, degree of task autonomy and independence in solving work-related problems (Zub, 2018; Prodanova et al., 2017).

2) The theory of expectations by V. Vroom states that a person's need is not the only condition for his or her motivation to achieve the goal (necessitated by the need). A person's expectation that his or her behavior and actions will lead to the desired result is an important condition. That is, a person's need is not enough; he or she needs to expect that his or her efforts will help to satisfy this need (Laužikas and Miliūtè, 2019).

3) The equity theory by D. Adams says that employees always subjectively evaluate the relationship between the remuneration received and the effort spent on achieving it, comparing it with the ratio of other workers performing the same work. That is, people often tend to think that they work more and get paid less than their colleagues. If a person thinks so, he or she feels the injustice (Aleksandrova \& Kurashova, 2015). The perceptions of justice can vary among workers, and the perceived ration of input and output is not always true. Therefore, the manager should track such contradictions and eliminate them in time (Thompson, 2016).

\section{Results}

The improvement of the technological process, the fight for customers, product quality, and increasing competition are forcing traders to improve the existing motivation system at an enterprise. As an object of study, the authors analyze the company "Novex"- the leading wholesale and retail enterprise in Siberia specializing in cosmetics, perfumery, household chemicals, and goods, founded in September 1990. The company was one of the first with a private form of ownership in the city of Barnaul, the administrative center of the Altai Territory of the Russian Federation. This explains the origin of the company's name - "the New Economic Structure", which later formed the abbreviation "Novex". The regional network of "Novex" shops in the Altai Territory is actively developing. In 2009, the company opened 13 retail stores in the Kemerovo Region, in Novosibirsk, and in the Altai Territory. In the spring of 2012, "Novex" continues to open new stores in the Tomsk and Novosibirsk Regions, as well as in the Altai Territory. In May 2012, Elena Viktorovna Filipchuk, the CEO of "Novex", was ranked 38th among the most influential women in Russian trade, according to the study by Retailer magazine, a leading trade magazine. Today "Novex" LLC has a network of 277 commercial enterprises. According to "Expert Siberia" magazine, "Novex" occupies the 17th place in the list of 100 biggest companies of the Altai Territory. Human potential and the manager's ability to set a goal correctly and effectively manage resources become the main success factors for the enterprise. The analysis has revealed a list of problems and solution (Table 1), which influence the performance of "Novex" LLC trading enterprise. 
Table 1. Problems and solutions influencing the performance of "Novex" LLC trading enterprise

\begin{tabular}{|l|l|}
\hline Problems & Solutions \\
\hline Underperformance, loss of sales; & Improving motivation tools \\
\hline Conflicts between managers and subordinates; & $\begin{array}{l}\text { - Clarification of requirements to the staff; } \\
\text { - Developing solutions to the conflict between } \\
\text { the manager and the employee }\end{array}$ \\
\hline $\begin{array}{l}\text { Avoidance of complex work by staff, } \\
\text { implementation of simpler orders; }\end{array}$ & $\begin{array}{l}- \text { Distribution of duties, according to the } \\
\text { position; } \\
- \text { Implementation of a mentorship system by } \\
\text { experienced personnel }\end{array}$ \\
\hline
\end{tabular}

Let us further examine each solution in detail.

1) Improving motivation tools:

Financial incentives at an enterprise might include salaries, bonuses, and additional payments. Thus, the authors suggest improving the existing system of personnel motivation. Below is the list of instruments for the financial motivation of personnel (Table 2).

Table 2. Proposed instruments for financial motivation of personnel in the trading enterprise LLC "Novex"

\begin{tabular}{|l|l|ll|}
\hline Instrument & Periodicity & Staff category \\
\hline $\begin{array}{l}\text { Employee discounts on the company's } \\
\text { products }\end{array}$ & Quarterly & $\begin{array}{l}- \text { Administrative and management } \\
\text { personnel; } \\
- \text { Sales staff; } \\
- \text { Junior service personnel }\end{array}$ \\
\hline Compensation of mobile expenses & Monthly & $\begin{array}{l}\text { Administrative and management } \\
\text { personnel }\end{array}$ & \\
\hline $\begin{array}{l}\text { Provision of vouchers to sanatoriums, } \\
\text { children's camps, to employees with } \\
\text { children under 15 years }\end{array}$ & Annually & $\begin{array}{l}\text { Administrative and management } \\
\text { personnel; } \\
- \text { Sales staff; } \\
- \text { Junior service personnel }\end{array}$ \\
\hline
\end{tabular}

When planning material incentives, the manager must proceed from the capabilities of an enterprise. The proposed tools of material motivation motivate personnel to further productive work at an enterprise. LLC "Novex" is confined to moral motivation (letters of appreciation, letters of gratitude, awarding the status of "the best seller"). Therefore, the authors would like to improve the instruments of nonmaterial personnel motivation (Table 3), since they require fewer material costs and are easily accessible to a developing enterprise.

Table 3. Suggested instruments of non-financial personnel motivation in a trading enterprise LLC "Novex"

\begin{tabular}{|l|l|l|}
\hline Instrument & Periodicity & Staff category \\
\hline Organizing corporate events & Quarterly & $\begin{array}{l}\text { - Administrative and management } \\
\text { personnel; } \\
- \text { Sales staff; }\end{array}$ \\
\hline
\end{tabular}




\begin{tabular}{|l|l|l|}
\hline & & - Junior service personnel \\
\hline $\begin{array}{l}\text { Granting "Novex" gift certificates in } \\
\text { the amount of } 1000 \text { rubles for the } \\
\text { performance of personal indicators }\end{array}$ & Quarterly & $\begin{array}{l}\text { - Administrative and management } \\
\text { personnel; }\end{array}$ \\
\hline $\begin{array}{l}\text { Assigning employees to educational } \\
\text { seminars and training courses in the } \\
\text { nearest cities }\end{array}$ & Annually & $\begin{array}{l}\text { - Junior service personnel } \\
\text { personnel; } \\
\text {-Sales staff }\end{array}$ \\
\hline
\end{tabular}

Based on Table 3, the burden of non-financial personnel motivation should fully become the responsibility of the company's head. In contrast to the bonus system, which activates the desire for high-quality performance of employees' duties, the system of non-material motivation should focus on increasing their loyalty to the company, motivating them for success, as well as developing their creative qualities and initiatives (Morozov et al., 2018; Bochkareva et al., 2018; Shklyarskiy et al., 2017a; 2017b; Prodanova et al., 2019; Nutskova and Kupavyh, 2016; Melnichuk et al., 2018a; 2018b; Movchan and Yakovleva, 2019a; 2019b). Moreover, the proposed elements of non-material motivation will increase the employees' efficiency and, consequently, the turnover of the company LLC "Novex".

2) Clarification of requirements to the staff:

Company executives need to clarify the results expected from each employee. It is necessary to mention such parameters as the level of results, obtaining information personally or through an intermediary, the system of responsibilities of each employee, the degree of responsibility. It is also necessary to clarify the rules for performing the objectives.

3) Developing solutions to the conflict between the manager and the employee:

a) compromise - improves the relationship between an employee and his/her manager, contributes to the successful implementation of objectives;

b) cooperation - implies a common solution when each approach to the problem is important and does not allow compromise options. Situation analysis and the search for additional information about the nature of the conflict are preferable than the immediate adoption of any decision (Plaskova et al., 2017). In any conflict, the manager needs to find a solution that will satisfy the interests of the two parties.

4) Distribution of duties, according to the position:

The manager must create a daily work plan for the staff; assign responsibilities according to their position. Each employee is responsible for the performance of his or her duties. It is possible to allow staff to act at their own discretion, to acquire skills and experience, learning from their own mistakes, in a way that is injurious or detrimental to the enterprise. The personal involvement of employees in the overall performance of an enterprise is essential at this stage.

5) Implementation of a mentorship system: 
Experienced staff needs to set an example for other employees of an enterprise - by performing orders of any complexity. A three-stage training ("describe - show do") is the most convenient and understandable form of mentoring:

a) "Describe". At this stage, the mentor needs to find out the level of knowledge of an employee and his or her understanding of the workflow. At the same time, the mentor must describe the features of the workflow within the enterprise and fill in the gaps in the theoretical knowledge of the employee.

b) "Show". This stage implies a practical demonstration of a complex workflow. The mentor needs to explain to the employee an algorithm of all the necessary actions to complete the required tasks (Kuznetsov et al., 2017).

c) "Perform". At this stage, the employee, using the obtained practical knowledge, tries to fulfill a complex task under the supervision of the mentor. The mentor needs to ensure control over the actions of the employee, monitor, correct possible errors if necessary, and access the results of the work.

In practice, this type of training requires a broader complementary approach to each of the stages. It should be remembered that consistent training workflow, especially through mentorship, is more effective than the simultaneous study of the entire spectrum of responsibilities (Dashko and Lebedeva, 2017. The abovementioned practices will help to address problems identified in the analysis of personnel motivation of the company LLC "Novex". An employee must be personally accountable for the work results, achievements and accomplishments, monitor his or her work results (Sharafutdinov et al., 2017; Nutskova et al., 2017). He or she must act in the common interests of an enterprise. A manager must realize that every employee strives for success. Success means the achievement of goals by an employee with maximum effort. Unrecognized success leads to disappointment, kills the initiative. That will not happen if the manager has the necessary expertise in the field of personnel motivation and successfully applies it in practice.

By way of conclusion, it can be said the analysis revealed that improving the quality of work is closely related to staff motivation. By applying in practice, the developed measures to improve personnel motivation, it is possible to improve the quality of labor in the trading enterprise LLC "Novex", which will further reduce production costs, increase enterprise profits, increase production flexibility and the quality of services, and improve the performance of the entire enterprise. All these motivation methods relate to external personnel motivation systems, that is, various ways to increase the efficiency of production behavior of the enterprise employees. However, there is another strong determinant of labor behavior - the internal motivation of personnel. The internal motivation of personnel is the employee's desire to perform the assigned work at the highest level, or vice versa, not do anything at all. Internal motivation explains why he or she prefers this or that type 
of activity. External motivation directly affects the behavior, but its effectiveness is limited, as it is perceived as an incentive or pressure. When an employee starts a new job, most often, his or her internal motivation is strong and is the main factor his determining behavior in the workplace. For many people, a new job is a new task, a new obstacle that one wants to overcome, an opportunity to acquire new skills and abilities (Abramovich et al., 2019).

The main objective of LLC "Novex" is to provide the necessary working conditions to the employees. For a positive influence on the internal motivation of its personnel, the company managers need to consider the factors of internal motivation:

1) Use employees' skills that they value themselves. Any manager knows how dangerous it is to hire an employee, who is too qualified for the position. If he or she suddenly agrees to this for any personal reasons (for example, for financial reasons), then after a few months, he or she will get bored and start looking for an application to his/her talents in other areas of activity. Until he/she finds another job that is more appropriate to his profile, he/she might attempt to "hook up" the manager or interfere in others' work with advice. Recommendations on the use of this factor of motivation are to appreciate any skill of each employee.

2) Consider the employee's ideas and initiatives. When starting a new job, employees usually suggest new ideas - from improving working methods to rearranging the furniture in an enterprise. The manager needs to listen and consider the proposed ideas, as he/she might find inspiration to part with the familiar working environment (Lincaru et al., 2018).

3) A sense of adherence to the enterprise. This factor of motivation is most relevant for employees working as support staff. A sense of belonging to a common cause is a strong incentive for employees. By sacrificing their personal interests and time, they are ready to work towards achieving the goals of the enterprise. Therefore, it is necessary to involve such employees in corporate events, regularly inform them about what is happening in the enterprise.

4) Recognize achievements and positive results of employees. The manager needs to notice any achievement of the employees, always encouraging them at least with verbal approval and support. In modern conditions, special attention should be paid to such factor of employees' behavior as internal motivation, although very often it remains neglected. This leads to negative consequences, hindering the effective work of personnel.

\section{Discussion}

The proposed tools of material and non-material motivation of personnel allow increasing productivity and, consequently, the profit of an enterprise. If previously 
the employees were not interested in the labor process and showed an indifferent attitude to work, then after the introduction of these activities' employees will become more active. Most of these incentives are costly and aimed at increasing revenues and profits. The authors assume that the implementation of all activities will increase the average annual revenue by $30 \%$. The costs of implementing the motivation tools are shown in Table 4.

Table 4. The cost of implementing motivation tools in a trading enterprise LLC "Novex"

\begin{tabular}{|c|c|c|}
\hline List of activities & $\begin{array}{l}\text { Solutions for the implementation } \\
\text { of activities }\end{array}$ & $\begin{array}{l}\text { Annual costs, thousand } \\
\text { rubles }\end{array}$ \\
\hline \multirow[t]{3}{*}{ Material motivation } & $\begin{array}{l}\text { Employee discounts on the } \\
\text { company's products }\end{array}$ & 65 \\
\hline & $\begin{array}{lll}\begin{array}{l}\text { Compensation } \\
\text { expenses }\end{array} & \text { of mobile } \\
\end{array}$ & 5 \\
\hline & $\begin{array}{l}\text { Provision of vouchers to } \\
\text { sanatoriums, children's camps, to } \\
\text { employees with children under } 15 \\
\text { years }\end{array}$ & 70 \\
\hline \multirow[t]{3}{*}{ Non-material motivation } & Organizing corporate events & 32 \\
\hline & $\begin{array}{l}\text { Granting "Novex" gift certificates } \\
\text { in the amount of } 1000 \text { rubles for } \\
\text { the performance of personal } \\
\text { indicators }\end{array}$ & 16 \\
\hline & $\begin{array}{l}\text { Assigning employees to } \\
\text { educational seminars and training } \\
\text { courses in the nearest cities }\end{array}$ & 8 \\
\hline Total & & 196 \\
\hline
\end{tabular}

Let us calculate the projected revenue from sales after the introduction of motivation incentives according to the formula (1):

$\operatorname{Pr}=(\operatorname{Srl}+(\operatorname{Srl} \times(\operatorname{Pir} / 100)))$

where Pr is the projected revenue from sales after the implementation of activities and limited to their influence, rubles;

$\mathrm{Srl}$ - sales revenue for the last period, rubles;

Pir - the projected increase in revenue from sales due to the implementation of the proposed program, $\%$.

$$
\operatorname{Pr}=(216,085+(216,085 \times(30 / 100)))=280,910.5 \text { thousand rubles }
$$

Then let us calculate the economic effect of the introduction of remuneration incentives according to the formula (2):

$\mathrm{E}=(\mathrm{Pr}-\mathrm{Ci})-\mathrm{Srl}$

where $\mathrm{E}$ is the economic effect of the introduction of remuneration incentives, rubles; 
$\operatorname{Pr}$ is the projected revenue from sales after the implementation of activities and limited to their influence, rubles;

$\mathrm{Ci}$ is the cost of implementing the activities, rubles;

$\mathrm{Srl}$ is sales revenue for the last period, rubles.

$$
\mathrm{E}=(280,910.5-196)-216,085=64,629.5 \text { thousand rubles. }
$$

Thus, it can be concluded that the economic effect of the proposed personnel motivation tools is positive since the costs of implementing the above methods amount to 196 thousand rubles against the increased turnover of 64,629.5 thousand rubles. The head of the trading enterprise "Novex" LLC must strive to create a favorable working atmosphere, by motivating the employees to:

- high-quality work performance;

- excluding any thoughts of theft or deception (in relation to customers and the head of the company);

- careful use of the equipment, maintaining order at the enterprise;

- protecting the company's interests during off-hours;

- taking responsibility for the team efforts.

These measures to increase personnel motivation will result in more efficient use of the labor potential and increase enterprise competitiveness in the market. The established team and corporate spirit in the enterprise will lead to improved sales and the strengthening of friendly team relations, respect and loyalty to the company.

\section{Conclusion}

In general, motivation is a term used to explain the behavioral sequence of actions aimed at a specific target, which can vary depending on various circumstances or situations. The concept of "motivation" includes moments of activation, management, and implementation of targeted human behavior. Motivation can explain a person acts this way or another. The study has confirmed the relevance of the topic. The results show the role and importance of the motivation system in an enterprise, its impact on achieving business goals.

Personnel motivation system is the weakest part of the trading company "Novex". Therefore, the authors suggest the company focus on the development of its motivation system. This implies developing in two directions:

1) Improving material personnel motivation;

2) Improving non-material personnel motivation.

The activities to improve the system of personnel motivation in a trading enterprise include:

- increasing the need for adherence in employees, both due to the possibility of 
corporate communication and through the development of teamwork, as well as involving employees in the process of joint decision-making;

- promoting the need for growth, development, self-expression in employees by developing their professional skills, achieving high results, participation in the enterprise activity;

- progressive teambuilding;

- increasing the employees' commitment to work, encouraging them to strive for common corporate goals;

By way of conclusion, it can be said that the improvement of the proposed system of personnel motivation will allow the company to create a favorable working atmosphere and eventually increase the turnover.

\section{References:}

Abramovich, B.N., Sychev, Y.A. \& Zimin, R.Y. 2019. The hybrid correction system, based on active and passive filters for harmonic compensation in networks of oil enterprises. Paper presented at the 2018 International Multi-Conference on Industrial Engineering and Modern Technologies, FarEastCon 2018, doi:10.1109/FarEastCon.2018.8602638.

Alexandrova, A.V., Kurashova, S.A. 2015. The role of Strategic Management: SPb textbook. Moscow: SIC strategic INFRA-M, 2015. 320 p.

Anurova, N.I. 2018. The staff in the trade organization. How to create a professional team. Moscow, 234p.

Blank, I. 2015. The Theory of Economic Analysis: studies. allowance. Moscow: University textbook, $222 \mathrm{p}$.

Bochkareva, T.N., Drozdov, V.A., Prikhodko, A.N., Gorbenko, A.V. \& Zakieva, R.R. 2018. Improving information and technical support of HR management system in the educational establishment. Paper presented at the Proceedings of the 31st BIMA 2018: Innovation Management and Education Excellence through Vision 2020, 3582-3589.

Brager, D.K., Pokramovich, O.V., Andreyko, M.N. \& Aleynikova, M.Yu. 2018. Modern theoretical and methodological approaches to personnel management in manufacturing enterprises. Espacios, 39(31).

Danko, T.P., Golubev, M.P. Sokolova. 2014. Management and Marketing, Strategic Graduate-Oriented Cost: A Textbook. Moscow: the cost of INFRA-M, 416 p.

Dashko, R.E. \& Lebedeva, Y.A. 2017. Contamination of water-saturated sandy-clay soils in the underground space of megalopolises and its connection to buildings long-term stability (the case study of Saint-Petersburg). Paper presented at the International Multidisciplinary Scientific GeoConference Surveying Geology and Mining Ecology Management, SGEM, 7(12), 151-158. doi:10.5593/sgem2017/12/S02.020.

Daryin, A.A., Maksimova, A.V., Telyakov, A.N. \& Fuks, A.M. 2015. Study of silicate bacterial destructive effect on quartziferous ores. Obogashchenie Rud, (4), 8-12. doi:10.17580/or.2015.04.02.

Domozhilkina, Zh.V., Jabbarova N.O. 2016. Development of a competitive strategy for agricultural enterprises. Interactive Science, 2, 139-142.

Dedyukina, V.V., Ronova G.N. 2015. The Role of Financial INFRA Strategy in Enterprise 
Management. The collection of scientific bachelor's works of faculty Electro staff, graduate students and Prospect masters of the department of the manual of Banking and English financial management. English Moscow, 175-181.

Goloshchapova, L.V., Plaskova, N.S., Prodanova, N.A., Yusupova, S.Y. \& Pozdeeva, S.N. 2018. Analytical review of risks of loss of profits in cargo transportation. International Journal of Mechanical Engineering and Technology, 9(11), $1897-$ 1902.

Kaverin, S.B. 2014. Labor motivation. M., Delo, 354 p.

Korableva, O.N., Kalimullina, O.V., Zaytseva, A.A. \& Larionov, A.I. 2018. Elaboration of database for the subject domain of innovation and economic growth potential. Paper presented at the Proceedings of the 31st International Business Information Management Association Conference, IBIMA. Innovation Management and Education Excellence through Vision 2020, 6065-6073.

Kuznetsov, V.S., Suprun, I.K. \& Petrov, D.S. 2017. Assessment and reduction of drilling waste impact on the environment components. Neftyanoe Khozyaystvo - Oil Industry, (1), 94-95.

Kuznetsov, V.S. \& Suprun, I.K. 2017. Reduction of an adverse impact during well drilling by means of drilling waste usage. Journal of Ecological Engineering, 18(2), 12-15. doi:10.12911/22998993/68211.

Laužikas, M., Miliūtè, A. 2019. Transformational Communication via Evolving Ethical and Moral Norms of Lithuanian Civil Service Organizations. Entrepreneurship and Sustainability, 6(4), 1750-1761. http://doi.org/10.9770/jesi.2019.6.4(14).

Lorincová, S., Hitka, M., Bajzíková, L., Weberová, D. 2019. Are the motivational preferences of employees working in small enterprises in Slovakia changing in time, Entrepreneurship and Sustainability Issues, 6(4), 1618-1635. https://doi.org/10.9770/jesi.2019.6.4(5).

Lincaru, C., Pirciog, S., Grigorescu, A., Tudose, G. 2018. Low-Low (LL) High Human Capital Clusters in Public Administration Employment - Predictor for Digital Infrastructure Public Investment Priority - Romania Case Study, Entrepreneurship and Sustainability Issues, 6(2), 729-753. http://doi.org/10.9770/jesi.2018.6.2(18).

Lyasko, A.K. 2015. Strategic management. St. Petersburg, Modern textbook. M., Publishing House Blake Case ANH, 488 p.

Melnichuk, M.S., Fokina, S.B., Boduen, A.Y. \& Petrov, G.V. 2018a. Co-recovery of platinum-group metals and chrome in processing of low-grade dunite ore material. Obogashchenie Rud, (1), 50-55. doi:10.17580/or.2018.01.09.

Melnichuk, M.S., Petrov, G.V., Fokina, S.B. \& Zotova, I.E. 2018b. Enhancing optimal performance of the platinum concentrates by reduction sulfuric acid. Acta Technica CSAV (Ceskoslovensk Akademie Ved), 63(3), 467-474.

Movchan, I.B. \& Yakovleva, A.A. 2019a. Approach to automation of field diagnosis data interpretation for localization of pitting in the pipeline wall. International Journal of Civil Engineering and Technology, 10(2), 1571-1581.

Movchan, I.B. \& Yakovleva, A.A. 2019b. Wave analogies for generalized description of geodynamic zones. International Journal of Innovative Technology and Exploring Engineering, 8(6), 863-868.

Morozov, I., Pavlyuk, A., Yumashev, A., Yumasheva, N. \& Gubarkov, S. 2018. Motivation of personnel in an innovative business climate. European Research Studies Journal, 21(1), 352-361.

Minasyan, S.S. 2014. Motivation of staff. Young Scientist, 1, 401-403.

Nutskova, M.V. \& Kupavyh, K.S. 2016. Improving the quality of well completion in 
deposits with abnormally low formation pressure. International Journal of Applied Engineering Research, 11(11), 7298-7300.

Nutskova, M.V., Dvoynikov, M.V. \& Kuchin, V.N. 2017. Improving the quality of well completion in order to limit water inflows. Journal of Engineering and Applied Sciences, 12(22), 5985-5989.

Nikolaeva, N.V., Aleksandrova, T.N. \& Taranov, V.A. 2017. Determination of the degree of impact destruction of gold-bearing ore particles in the layer. Information (Japan), 20(9), 6605-6613.

Plaskova, N.S., Prodanova, N.A., Zatsarinnaya, E.I., Korshunova, L.N. \& Chumakova, N.V. 2017. Methodological support of organizations implementing innovative activities investment attractiveness estimation. Journal of Advanced Research in Law and Economics, 8(8), 2533-2539. doi:10.14505/jarle.v8.8(30).25.

Prodanova, N.A., Smolentsev, V.M., Norkina, A.N., Shukshina, Y.A. \& Polyanskaya, O.A. 2017. Formation of system of internal control and features its functioning in the innovative development of industrial enterprises. International Journal of Applied Business and Economic Research, 15(13), 179-189.

Prodanova, N.A., Trofimova, L.B., Adamenko, A.A., Erzinkyan, E.A., Savina, N.V. \& Korshunova, L.N. 2019. Methodology for assessing control in the formation of financial statements of a consolidated business. International Journal of Recent Technology and Engineering, 8(1), 2696-2702.

Repina, E.A. 2016. The basics of Ekaterinburg management: Dorofeev study guide. M ., Publishing Academtsentr, $240 \mathrm{p}$.

Rozanov, V.A. 2014. Psychology of management. Tutorial. Moscow: Intel-Sintez Business School, $352 \mathrm{p}$.

Serbinsky, B.Yu., Samygina S.I. 2015. Human Resource Management: A Textbook for High Schools, 384 p.

Sharafutdinov, R.I., Gerasimov, V.O., Yagudina, O.V., Dmitrieva, I.S., Pavlov, S.V. \& 2017. Research of human capital in view of labour potential of staff: National companies case study. Paper presented at the Proceedings of the 29th IBIMA Conference, 839-852.

Shklyarskiy, Y.A.E. \& Shklyarskiy, A.Y.A. 2017a. Registration of reactive power for case of distortions in electric grid. Paper presented at the IOP Conference Series: Earth and Environmental Science, 87(3). doi:10.1088/1755-1315/87/3/032041.

Shklyarskiy, Y.E., Shklyarskiy, A.Y. \& Belitskiy, A.A. 2017b. The compensation criterion of overload neutral wire current in low voltage electrical networks. Paper presented at the Proceedings of the 2017 IEEE Russia Section Young Researchers in Electrical and Electronic Engineering Conference, ElConRus, 1012-1015. doi:10.1109/EIConRus.2017.7910728.

Solomatina, N.A., Porshnev, A.G., Rumyantseva, Z.P. 2016. Organization Management: Textbook. Moscow: SIC INFRA-M, $736 \mathrm{p}$.

Thompson, A.A. 2016. Strategic Mokronosov Management: Concepts and Ganiev Situations for Ed. Analysis. Translated from English. Moscow: Williams, 928 p.

Zub, A.T. 2018. Management Strategic Management: a scientific study guide. Moscow: Yurayt, $375 \mathrm{p}$. 